\title{
Metody budowy pojęcia zbioru w problemie interpretacji tez Hui Shi
}

\section{Methods of building of set concept in interpretation problem of Hui Shi's thesis}

\author{
Stawomir Sikora \\ INSTYTUT JĘZYKOZNAWSTWA, UNIWERSYTET IM. ADAMA MICKIEWICZA \\ AL. NIEPODLEGŁOŚCI 4, 61-874 POZNAŃ
}

\begin{abstract}
The article presents an alternative conception of the problem of interpretation of the shortest and also most enigmatical text of Chinese philosophy, i.e. the ten theses of Hui Shi.

Leśniewski claimed that the source of Russell's difficulties with antinomies is related to a lack of distinction between a distributive and a collective class.

Mereology is the logic of a certain concrete whole constituted by the parthood relations of a collective class. The use of Leśniewski's formal solutions in the analysis of thesis (8) of Shi Hui:

Linked rings can be disconnected, shows that in Chinese philosophical discourse two kinds of set theory were applied: distributive and collective.

This is confirmed by thesis (5): When it is said that things greatly alike are different from things a little alike, this is what is called making little of agreements and differences; (when it is said that) all things are entirely alike or entirely different, this is what is called making much of agreements and differences.

Therefore the hypothesis seems plausible that the paradox of Hui Shi's theses was the result of a dualistic formulation of the world order: on the one hand by the distributive order of distinguishing things by their names, on the other by the collective order of embracing all things within the frame of a common Universe.
\end{abstract}


Artykuł ma na celu przedstawienie alternatywnego rozwiązania problemu interpretacji najkrótszego, a zarazem najbardziej zagadkowego tekstu filozofii starochińskiej, którym jest dziesięć tez mistrza Hui Shi. Na przykładzie tez spróbuję uzasadnić hipotezę o tym, że metody konstrukcji pojęcia zbioru w istotny sposób oddziaływały na teoriopoznawcze strategie porządkowania procesów poznawczych w kulturze starożytnych Chin. W części wstępnej zarysowuję metody ujęcia pojęcia zbioru w tradycji zachodniej.

\section{WYMOWA W TRANSKRYPCJI PINYIN}

Wymowa liter zastosowanej w artykule transkrypcji znaków chińskich na alfabet łaciński, została uproszczona, ponieważ nie zaznaczono w niej tonów ( z wyjątkim tekstu głównego):

$>$ spółgłoski dźwięczne (b, d, g, z) wymawia się jak bezdźwięczne (p, t, $\mathrm{k}, \mathrm{dz}$ ),

$>$ spółgłoski bezdźwięczne (p, t, k, c) wymawia się z przydechem,

$>$ połączenia dwuliterowe (zh, ch, ng, sh) oraz spółgłoski „w" i „y" wymawia się jak w języku angielskim (dż, cz z przydechem, n tylnojęzykowe, sz, $1, \mathrm{j}$ ),

>,r” na początku wyrazu jak „ż", ,j" wymawia się jak „ćc", „q" jak „ćc z przydechem, „x" jak „ś".

\section{Nota biograficzna}

Hui Shi (chin. 惠施,huishi) (ok. 350-26o p.n.e) był chińskim mędrcem pochodzącym z prowincji Song. Ze względu na swoje wszechstronne wykształcenie pełnił funkcję ministra w rządzie króla Hui w państwie Wei. $\mathrm{Na}$ dworze tytułowano go Uncle to the King. W historii filozofii chińskiej znany jest przede wszystkim jako sprawny dialektyk, bystry teoretyk prawa, mędrzec gorąco i wnikliwie rozprawiający nad problemami ontologii, teorii poznania oraz nauki.

Bezpośrednim i głównym źródłem informacji na temat biografii, jak i poglądów Hui Shi są chińskie księgi: Prawdziwa Księga Potudniowego Kwiatu Zhuangzi (Czuang-Tsy 1953), Xunzi (Knobloch 1994) oraz The annals of Lü Buwei (Knobloch, Riegiel 2000).

The annals of Lü Buwei (chiń. 呂氏春秋, Lüshi chunqiu) jest zredagowanym w 3 wieku p.n.e. kompendium wczesnej historii i filozofii chińskiej. Odnajdziemy w nim spójne opracowania dotyczące Konfucjanizmu, Daoizmu, Moizmu i Legizmu. 

interpretacji tez Hui Shi

W części 18 księgi zawarte są wzmianki o mistrzu Hui Shi - autorze analizowanego przeze mnie tekstu. Hui Shi określa się tam mianem wzorca intelektualnej ignorancji, ostro krytykuje się jego kompetencje polityczne i zarzuca się mu po prostu głupotę (Knobloch, Riegel 2000: 438-468).

Również krytycznie w stosunku do poglądów, aczkolwiek już z dużą dozą sympatii i szacunku, pisze o Hui Shi jego przyjaciel Zhuangzi (chin. 庄子, Zhuangzi).W jego opinii wyrażonej w XXXIII rozdziale Prawdziwej Księgi Potudniowego Kwiatu, Hui Shi (...) przez caty czas wysilat swoja wiedze, by rozprawiać z innym $i$ z rozmystem czynił z tego widowiska. Chociaż usta jego mówity czcze słowa, sam uważat siebie za najmadrzejszego (Czuang-Tsy 1953: 340 - 341.). Po śmierci mistrza Zhuangzi szczerze ubolewał po stracie najlepszego swego interlokutora - nie mam, do kogo mówić (Czuang-tsy 1953: 259).

Przez historyków filozofii Hui Shi został przypisany do tzw. Szkoty Nazw (ang. School of Names). Pojęciem tym określa się grupę filozofów chińskich okresu Warring States (479 - 221 p.n.e). Uczeni Szkoty Nazw koncentrowali swoją uwagę na problematyce z pogranicza filozofii języka i teorii argumentacji. Ze względu na to, że ich zainteresowania zogniskowane były na relacji między nazwą (chin. 名, ming) a rzeczą (chin. 事, shi), zwykło się ich określać mianem bianzhe (chin. 编者, bianzhe) - dialektycy, polemiści, toczący spory. Do szkoły tej zaliczano takich mistrzów jak: Deng Xi, Huan Tuan, Hui Shi oraz Gongsun Longa. Co charakterystyczne dla tej grupy, wszyscy jej członkowie wykonywali zawód prawnika.

Chociaż - jak uznał Zhuangzi - Hui Shi był bardzo pomysłowy, a jego pisma wypełniały pięć wozów (Czuang-tsy, 1953: 340), dziś dorobek mistrza analizowany jest głównie z perspektywy tzw. paradoksów przekazanych nam za pośrednictwem Prawdziwej Księgi Południowego Kwiatu. Całość jego pism zaginęła i być może cierpliwie czeka na ponowne odkrycie.

Krótką notę biograficzna zakończę słowami - cieszącego się wśród współczesnych badaczy filozofii i logiki starożytnych Chin dużym autorytetem Angusa Charlesa Grahama:

The sparseness of the remains of Hui Shih is perhaps the most regrettable of all the losses in ancient Chinese literature, for everything recorded of him suggests that he was unique among the early thinkers for his breadth of talents and interests, a true Renaissance man. The leaders of most schools aspired at least in theory to guide some ruler on the path they identified as the Way; but if we except the great statesmen to whom some Legalist works are dubiously ascribed, they were lucky to get even minor offices or sinecures. How did a sophist become chief minister in the state of Wei? And how is it that we keep meeting this most successful man of the world in the company of that disreputable lay about Chuang-tzu, who mocks his rigid logic but laments him after his death as his only truly stimulating opponent? Not that his various roles are incompatible, for from a direction different from Chuang-tzu's his fellow statesmen, too, see him as having too theoretical a mind (Graham 1986: 76). 


\section{Tekst i jego interpretacja}

Dziesięć tez mistrza Hui Shi zostało przedstawionych w XXXIII rozdziale Prawdziwej Księgi Potudniowego Kwiatu Zhuangzi zatytułowanym Poglądy na świat. Ich przekład na język polski pochodzi od wybitnego znawcy logiki chińskiej, sinologa - Janusza Chmielewskiego. Wymienione w księdze tezy nie są opatrzone przez autora żadnym komentarzem. Na chwilę obecną nie można odpowiedzieć, czy porządek tez w księdze pochodzi od samego Hui Shi, czy też jest on intencjonalnie narzucony przez samego Zhuangzi.

Problem ten staje się istotny podczas próby zamknięcia tez w jeden spójny, choć bez wątpienia lapidarny, system filozoficzny.

Lista tez w języku chińskim:

至大無外, 謂之大一; 至小無內, 謂之小一。無厚不可積也, 其大千里。天 與地卑，山與澤本。日方中方睨，物方生方死。大同而與小同異，此之謂小 同異；萬物畢同畢異，此之謂大同異。南方無窮而有笨，今日適越而昔來。 連環可解也。我知天下之中央, 燕之北, 越之南是也。汇愛萬物, 天地一體 也。

Zhì dà wú wài, wèi zhī dà yī; zhì xiăo wú nèi, wèi zhī xiăo yī. Wú hòu bù kě jī yě, qí dà qiān lǐ. Tiān yǔ dì de bēi, shān yǔ zé píng. Rì fāng zhōng zhòng fāng ni, wù fāng shēng fāng sǐ. Dà tóng ér yǔ xiăo tóng yì, cǐ zhī wèi xiăo tóng yì; wàn wù bì tóng bì yì, cǐ zhī wèi dà tóng yì. Nán fāng wú qióng ér yǒu qióng. Jīn rì shì yuè huó ér xī cuò xí lái. Lián huán jiě jiè xiè kě yě. Wǒ zhī tiān xià zhōng zhòng yāng. yàn yān zhī běi. yuè huó zhī nán shì yě. fàn fán fěng ài wàn wú Tiān dì de tǐ tī ȳ̄ yě (Destrugon 2010, http://ctext.org/zhuangzi/tian-xia, 10.02.2011).

W przekładzie Janusza Chmielewskiego czytamy:

1. Największą wielkość, poza którą nie ma nic, nazywam wielką jednostką. Najmniejszą małość, wewnątrz której nic nie ma, nazywam małą jednostką.

2. To, co nie ma grubości, nie może być gromadzone, a jednak może być wielkie na tysiąc mil.

3. Niebo jest równie niskie jak ziemia; góry są równie płaskie jak mokradła.

4. Słońce w zenicie już chyli się ku zachodowi; istota rodząc się, zaczyna umierać. 


\section{Stawomir Sikora: Metody konstrukcji pojęcia zbioru w problemie interpretacji tez Hui Shi}

5. Wielkie podobieństwo jest odmienne od małego podobieństwa; nazywam to małą różnicą podobieństw. Wśród mnogości przedmiotów wszystkie są pod pewnym względem podobne i pod pewnym względem odmienne; nazywam to wielką różnicą podobieństw.

6. Południowa strona świata nie ma granicy i zarazem ma granicę.

7. Dzisiaj wyruszam do Jüe, lecz już dawniej tam przybyłem.

8. Połączone pierścienie dają się rozłączyć.

9. Wiem, gdzie leży środek świata: na północ od Jen i zarazem na południe od Jüe.

10. Jednakową miłością otaczajmy wszystkie istoty; niebo i ziemia stanowią jedno ciało (Czuang-Tsy 1953: 340-441).

We współczesnej literaturze traktującej o filozofii i logice chińskiej, za trendem interpretacyjnym wytyczonym przez Grahama w książce Disputers of the Tao: Philosophical Argument in Ancient China, tezy Hui Shi nazywa się paradoksami. Graham dostrzegł w tezach pewną homogeniczną własność determinującą paradoksy. Utrzymuje on, że to proces nieskończonego podziału skończonych elementów (znany przede wszystkim w filozofii zachodniej dzięki szkole Eleatów) skutkuje rozumowaniem paradoksalnym (Graham 1986: 77).

W duchu greckiej tradycji logicznej, dokonana przez Grahama interpretacja przedstawia się następująco:

(1) Counting is relative to division; either the infinite whole or the indivisible point which is its smallest division may be counted as one.

(2) The indivisible division presents a paradox; any quantity is the sum of its smallest divisions, yet the sum of points remains a point.

(3) The infinite whole presents another paradox; since from any position the distance upwards and downwards is infinite, mountains should be level with marshes.

(4) The indivisible division of time, the moment, likewise presents a paradox; the last moment of life is the first of death, so a thing is simultaneously alive and dead.

(5) In dividing and naming, we assume that we can give, for example, the name 'horse' to objects similar to each other and different from other objects but if we push similarity and difference further horses turn out to be both different from each other and similar to everything else.

(6) Space presents the further paradox that it both must and cannot have a limit.

(7) Combining the indivisible divisions of space and time, it appears that if I cross the line between one state and another at the moment between one day and the next, I both left one state today and reached the other yesterday.

(8) If indivisible divisions truly exist, it follows that connected rings can be fined down to pure circles and passed through each other without resistance.

(9) Space if infinite has its centre everywhere. 
(10) Since division leads to contradiction don't divide at all, and therefore be as concerned for all other things as for yourself.

Zgodnie z deklaracją Grahama całość zaproponowanej analizy oparta jest na analogii konstrukcyjnej do paradoksów Zenona z Elei. Odwołuje się on bezpośrednio do paradoksu Achillesa i żótwia oraz zgodnie z interpretacją tezy (2), do sprzeczności: podzielne jest niepodzielne, co dalej prowadzi do paradoksu strzaty.

Spójność prezentowanej argumentacji Grahama zbudowana jest na koniunkcji obu paradoksów.

Dla jasności dalszych rozważań przypomnijmy dwa wspomniane wyżej paradoksy Zenona.

Achilles rozpoczyna wyścig z żółwiem, który ma nad nim przewagę $n$ metrów. Przypuśćmy, że żółw biegnie dziesięć razy wolniej niż Achilles. Kiedy Achilles dotrze do miejsca, z którego startował żółw, ten znajdzie się $n / 10$ odległości z przodu. Kiedy Achilles dobiegnie do tego punktu, żółw będzie się znajdował $n / 100$ metrów z przodu, itd. Bardzo ważne jest to, że podział taki dokonuje się ad infinitum.

Ciąg pojedynczych, skończonych punktów podziału tworzy nieskończone kontinuum jej elementów.

W analogii do paradoksu Achilesa i żłowia Graham dokonał interpretacji paradoksu (3) Hui Shi.

W drugim paradoksie Zenona strzała nie może poruszać się w miejscu, w którym jej nie ma. Nie może także poruszać się w miejscu, w którym jest. Jednakże lecąca strzała zawsze znajduje się w miejscu, w którym jest. Znaczy to, że w dowolnej chwili pozostaje w spoczynku. Jeżeli w żadnej chwili się nie porusza to pozostaje w miejscu. Jeżeli potraktujemy tor strzały jako linię składającą się z bezwymiarowych punktów i jeżeli przyjmiemy, że czas składa się z pojedynczych i nieciągłych momentów, to ruch jest spoczynkiem. Ruch postrzegany jako suma pojedyńczych i niepodzielnych elementów, sam podzielny być nie może. Ruch nie istnieje (Blackburn 1994: 284285).

Tak oto, niewłaściwie użyte pojęcie nieskończoności i sprzeczność podzielne/niepodzielne - analogicznie jak miało to miejsce w filozofii zachodniej - prowadzą zdaniem Grahama do paradoksów Hui Shi.

W mojej jednak opinii, odczytanie tez Hui Shi w kategoriach paradoksu nieskończoności wzbudza pewne wątpliwości.

Wątpliwość pierwsza ma charakter filozoficzno-kulturowy i związana jest z konsekwencjami metafizycznymi paradoksu strzały Zenona. Jak wiadomo, argumentacja Zenona ma, w zgodzie z eleacką teorią niezmienności bytu, służyć za dowód nieistnienia ruchu. Eleaci zastosowali logiczną zasadę sprzeczności w ontologicznej argumentacji na rzecz nie istnienia niebytu. Problem jedności bytu rozwiązywali przez zaprzeczenie wszelkiej różności (Diogenes Leartios 1984: 527-534).

W filozofii daoistycznej odwrotnie, idzie raczej o to, aby ukazać permanentną zmienność świata zjawisk, a temu celowi nie służy z pewnością argumentacja na rzecz nie istnienia ruchu. 
Wzmacniając tę wątpliwość przykładem, przywołam słowa przyjaciela Hui Shi - daoisty Zhuangzi:

Życie istot jest jak pęd rumaka, jak galop konia, a nie ma ruchu, który by nie byt zmiana, i nie ma chwili, która by nie była przekształceniem (Czuang - Tsy 1958: 187).

Jak pomieścić wobec tego $\mathrm{w}$ koncepcji ontologicznej, bez popadania $\mathrm{w}$ sprzeczności jedność i wielość?

Tradycja chińska rozwiązuje problem jedności w różnorodności -... byt $i$ niebyt rodza siebie nawzajem, tatwe i trudne wzajemnie wzrastaja, długie i krótkie przydaja sobie ksztattów (...) razem tworzą harmonię kolejno się dokonuja - to, co poprzedza, dla tego, co następuje po nim wzajemnie (Lao Tsy 2006: 28).

Teza (7): Dzisiaj wyruszam do Jüe, gdzie już dawniej tam przybyłem, może wobec powyższego być interpretowana jako:

Miasto, do którego przybyłem wczoraj, już nie jest tym samym Jüe, $w$ którym jestem dziś.

Wątpliwość druga ma charakter logiczno-semantyczny. W paradoksie „Achillesa i żółwia” nieskończoność ma charakter kontinuum, a zastosowana do interpretacji tezy (2) i (3) wydaje się być w konflikcie z tezą (1), w której zarówno najmniejsza wielość, jak i największa wielość - w jednoznaczny sposób zamyka się w całość nazwaną jeden. Nieskończoność jako kontinuum i nieskończoność jako całość to dwa skrajnie różne pojęcia, oraz dwie skrajnie różne teorie je opisujące.

Mając na uwadze zdecydowaną niechęć starożytnej matematyki chińskiej do geometrii, na gruncie preferowanej przezeń arytmetyki zakłada się, że każde liczenie, nawet dziesięciu tysięcy rzeczy, jak zwykło się w tej tradycji określać nieskończoność, zamyka się ostatecznie w całości. Każde liczenie ma swoją skończoną granicę w górę - jedność (chin. 大 一, da yi) oraz w dół -jedność (chin. 小一, xiao yi).

Przyjęcie takiego stanowiska zakłada istnienie nieskończonej całości nazwanej jeden, poza którą nie ma już nic i jeden, wewnątrz którego nie ma niczego. Nieskończoność w tezie (1) jest całościa, w przeciwieństwie do zakładanej w paradoksie Achillesa i żółwia nieskończoności, jako kontinuum.

Poddaną tutaj pod wątpliwość wyznaczoną przez Grahama linię eksplikacyjną tekstu Hui Shi, odnajdujemy również między innymi w zorientowanej na komparatystyczną analizę problematyki logicznej pracy Christopha Harbsmeiera Science and Civilisation in China. Language and Logic (Harbsmeier 1998).

\section{Nieskończoność, intensjonalność i ekstensjonalność w dystrybutywnej konstrukcji pojęcia zbioru}

Najstarsze znane w kulturze Zachodu sformułowanie problemu pojęcia nieskończoności wiąże się z wyrażeniem matematycznego związku między przekątną kwadratu a jego bokiem. W szkole greckich 
Pitagorejczyków odkryto, że liczba wyrażająca tą zależność jest liczbą niewymierną $(\sqrt{ } 2)$. Niechciana konsekwencja problemu matematycznej nieskończoność doprowadziła szkołę pitagorejczyków do intelektualnego kryzysu w mistycznym ujęciu metafizycznej kategorii arche.

Problemy z nieskończonościa doskonale egzemplifikował Proklos Diadochus (410-485) w Komentarzu do I księgi Elementów Euklidesa. Argumentował on, że średnica dzieli koło na dwie równe części. Jeżeli jednak za pomocą jednej średnicy powstają dwa półkola i jeżeli przeprowadzić przez środek nieskończenie wiele średnic, to okaże się, że półkoli będzie dwa razy więcej niż nieskończenie wiele (Murawski 1986: 50-58).

Tysiąc lat po Proklosie, Galileusz sformułował paradoks w istocie nie wiele różniący się od jego starożytnego poprzednika. Liczby kwadratowe 1, 4, 9, $16, \ldots$ są częścią właściwą ogółu wszystkich liczb naturalnych, ale jest ich jednocześnie tyle samo, co liczb naturalnych. Błąd zdaniem Galileusza tkwi w tym, że naszym skończonym umysłem staramy się uchwycić i orzekać o wielkościach nieskończonych, że jedne z nich są większe, mniejsze bądź też równe ( Murawski 2001: 174).

Roman Murawski twierdzi, że wszystkie tzw. paradoksy nieskończoności oparte były na założeniu, które odnajdujemy już w Elementach Euklidesa, gdzie czytamy, iż całość jest większa od części (Murawski 2001: 176)1.

Do momentu ukazania się w XIX w prac Bernarda Bolzano, Georga Cantora i Gottloba Fregego w kwestii rozwiązania paradoksów dotyczących nieskończoności, filozofia zachodnia dreptała w miejscu. W ramach ciągnącego się przez dwa tysiąclecia sporu o uniwersalia, interesowała się przede wszystkim ontologicznym statusem pojęcia zbioru.

Solidny fundament pod prace, które w efekcie zakończyły się sformułowaniem w 1914 przez Ernesta Zermelo niesprzecznej teorii mnogości i teorii typów Bertranda Russell'a, wnosiły prace Richarda Dedekinda i Cantora z zakresu badań teorii zbiorów i nieskończoności, oraz całkowicie nowatorskie opracowania Fregego z zakresu semantyki logicznej i zaksjomatyzowanej postaci systemu logicznego.

Przełomem wydaje się być praca Dedekinda Was sind und was sollen die Zahlen?. Autor zdefiniował w niej po raz pierwszy w historii myśli zachodniej pojęcie zbioru nieskończonego. ${ }^{2}$

\footnotetext{
1 Przytoczona opinia Murawskiego prawdopodobnie odnosi się tylko do paradoksów filozofii zachodniej.

2 Dowód Dedekinda na istnienia zbioru nieskończonego w zarysie wyglądał następująco:

Twierdzenie: Każdy system złożony z jednego elementu jest skończony.

Dowód. System taki nie posiada bowiem części właściwych.

Twierdzenie: Istnieją systemy nieskończone.

Świat moich myśli (meine Gedankenwelt), tzn. całość $S$ wszystkich rzeczy, które mogą być przedmiotem mojego myślenia, jest nieskończony. Istotnie, jeżeli s jest elementem $S$, to tak samo myśl s', że $s$ może być przedmiotem mojego myślenia, jest sama elementem $S$. Jeżeli potraktować $s$ ’jako obraz f(s) elementu s, to określone przez to odwzorowanie $f$ systemu $S$ ma tę własność, że obraz $S^{\prime}$ jest częścią $S$; mianowicie $\mathrm{S}^{\prime}$ jest częścią właściwą $S$, ponieważ są w $\mathrm{S}$ elementy (np. moje własne Ja, które są różne od wszystkich takich myśli $s$ 'i dlatego nie należą do $S^{\prime}$ ). Ostatecznie staje się jasne, że gdy a i $b$ są różnymi elementami $S$, to także ich obrazy są różne, a więc, że odwzorowanie $f$ jest dokładne (podobne). W konsekwencji $S$ jest nieskończone (Dedekind 1888, w: Murawski 1986: 155.)
} 

interpretacji tez Hui Shi

Dedekind nazwał zbiorem nieskończonym całość będącą zbiorem wszystkich rzeczy. Krok ten, polegający na zamknięciu nieskończoności w formie całości był na tyle istotny, że otwarł drogę Cantorowi do ekstensjonalnej definicji zbioru i zarysowania wyraźniej granicy między nieskończonościa aktualna a nieskończonościa potencjalną.

Nieskończoność potencjalna - jak wiadomo - odnosi Cantor do pewnych zmiennych wielkości nieskończonych, które rosną poza wszelkie skończone granice lub stają się mniejsze niż każda granica (Cantor 1986: 160-165). Nieskończoności potencjalne nie są jednocześnie jednościami, tzn. takimi wielkościami, których realne istnienie razem wszystkich ich elementów (niem: ein reales Zusammensein aller ihrer Elemente) jest niemożliwe. Nieskończonościa aktualna nazywa natomiast wielkość, która z jednej strony jest we wszystkich swych częściach stała i określona, tzn. jest prawdziwą stałą, z drugiej zaś strony przekracza każdą wielkość skończoną tego samego rodzaju, na przykład, ogół wszystkich skończonych liczb całkowitych dodatnich.

Z perspektywy ontologicznej nieskończoność potencjalna nie jest nieskończonością właściwą. Przysługuje jej pewne pozorne istnienie.

Realizm ontologiczny odnosi Cantor tylko do nieskończoności aktualnej. Odnajduje ona swoją realizację w trzech różnych formach: nieskończoność aktualna absolutna (urzeczywistniająca się w Bogu), nieskończoność aktualna ukazująca się w świecie stworzonym przez Boga oraz nieskończoność aktualna in abstracto będąca wielkością matematyczną.

Cantor zauważył, że zbiór $\mathrm{w}$ jego rozumieniu jest spokrewniony z platońskim pojęciem $i \delta \varepsilon \alpha$, i zdecydowanie przeciwstawia go nieokreślonemu,

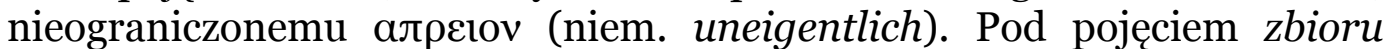
(niem. Mange) rozumieć należy każdą wielość (niem. jedes Viele) M określonych przedmiotów m, które ujęte są jako jedność (niem. als Eines), tj. ogół określonych elementów, które na mocy pewnego prawa mogą być złączone w pewną całość (Cantor 1986:157). In abstracto każdemu zbiorowi M przysługuje pewna określona moc (niem. Mächtigkeit), którą nazywa się liczbą kardynalną (niem. Kardinalzahl). Moc zbioru jest pojęciem ogólnym (niem. Allgemeinbegriff), które za pomocą naszej zdolności aktywnego myślenia bierze swój początek ze zbioru M w ten sposób, że abstrahuje się od jego różnych elementów m i od porządku, w jakim są dane (Cantor 1986: 158).

Konstrukcję zbiorów zaprezentowaną przez Cantora można nazywać iteracyjną. Pojęcie iteracji często określa się za pomocą klasy abstrakcji. Dowolną klasę wszystkich izomorficznych podsystemów systemu nazywa się iteracją. Cantorowskie liczby kardynalne są iteracjami: Niech $<\mathrm{U}, \mathrm{R}>$ będzie systemem iteracyjnym, w którym $U$ jest dowolnie ustalonym nieskończonym zbiorem, a rodzina relacji $\mathrm{R}$ jest pusta. Wtedy dowolny podzbiór U wyznacza podsystem tego systemu iteracyjnego, a iteracja jako klasa wszystkich izomorficznych podsystemów jest klasą wszystkich równolicznych zbiorów, tj. jest liczbą kardynalną. Również liczby porządkowe są iteracjami. 
Niestety, znana argumentacja Cantora o zbiorze przekątniowym pokazała, że sama iteracyjna konstrukcja zbioru nie chroni przed paradoksalnymi konsekwencjamis.

Gottlob Frege, w odróżnieniu od Cantora, utożsamia pojęcie zbioru (lub raczej właściwiej będzie powiedzieć zakres pojęć) z ekstensją funktorowych wyrażeń językowych - pojęć i funkcji. W tekście $Z$ uwag o sensie $i$ znaczeniu (po 1892) przyjmuje powszechnie uznany na gruncie realizmu semantycznego pogląd, że znaczeniem nazwy jest przedmiot przez nią oznaczany. Znaczeniem predykatu nie jest jednak ani pojedynczy przedmiot, ani wielość przedmiotów, ale jest pojęcie, o ile termin ten rozumiemy logicznie. Klasa (zbiór) przedmiotów spełniających dane pojęcie nazywa się zakresem4. Zakresy pojęć nie są pojęciami, ale przedmiotami. Z punktu widzenia logiki pojęcia różnią się między sobą o tyle, o ile różnią się ich zakresy. Predykaty, bez uszczerbku dla prawdziwości zdań, w których występują, mogą być wzajemnie wymienialne, jeśli tylko odpowiada im ten sam zakres (Frege, 1977: 130-131). Zakres rozumie Frege jako zbiór przedmiotów spełniających dane pojęcie językowe i posiadających określoną własność. Intensja pojęcia wyznacza zbiór przedmiotów je spełniających. Zbiór, zatem w semantycznej koncepcji Fregego tworzony jest od dołu, kierunek prowadzi od języka do świata jego odniesienia. Dla przykła$\mathrm{du}$, zakresem pojęcia wyrażanego przez predykat $\mathrm{P}(\mathrm{x})$ jest klasa przedmiotów x to pojęcie spełniających5.

Nie ma możliwości zdefiniowania na gruncie semantyki logicznej Fregego wyrażenia zbiór bez odwołania się do wyrażenia zakres pojęcia.

Powracając do cytowanego pytania B. Russell'a:

Niech „w” będzie taka własnością, że bycie „,w’ jest własnością, która nie może być orzekana o samej sobie. Czy „w” może orzec o niej samej?, dostrzegamy w koncepcji Fregego znaczącą trudność. Mianowicie, nie zawsze jest tak, że istnieje zakres przedmiotów spełniających dane pojęcie, nie

\footnotetext{
3 Trudność owa wynika $\mathrm{z}$ próby porównania mocy zbioru wszystkich zbiorów i jego zbioru potęgowego. Zgodnie z twierdzeniem Cantora o zbiorze potęgowym, zbiór taki musi być podzbiorem wszystkich zbiorów i zarazem być liczniejszy od niego (ang. paradoxes of size). Podobnie jak wiele innych paradoksów, twierdzenie Cantora nie jest sprzecznością, ale jedynie wskazuje na błędne intuicje naiwnej teorii mnogości związane $\mathrm{z}$ pojęciem zbioru i nieskończoność. Analogicznie budowany jest paradoks Burali-Fortiego o liczbach porządkowych.

4 Zarówno Frege jak i Russell w swoich teoriach nie dokonali wyraźnego rozróżnienia dwóch pojęć: klasa i zbiór. Używali ich zamiennie. Współcześnie terminu zbiór stosuje się dla oznaczenia zbioru ekstensjonalnego, natomiast termin klasa odnosi się do zbiorów rozumianych jako zakresy pojęć. 5 W roku 1903 w liście skierowanym do G. Fregego, B. Russell napisał:

Wcześniej wierzyłem $w$ to, teraz jednak poglad taki wydaje się mi watpliwy z powodu następujacej sprzeczności. Niech w będzie taka oto wlasnością: być własnościa, która może być orzekana o sobie samej. Czy w można orzec o niej samej? Z każdej odpowiedzi na pytanie wynika odpowiedź przeciwna. Musimy zatem wyciagnąc wniosek, że w nie jest wlasnością. Podobnie nie istnieje żadna klasa, (jako całość) złożona z tych klas, które, każda wzięta, jako całość, nie należa do samych siebie. Wnoszę stad, że w pewnych warunkach definiowalne kolekcje nie tworza gotowych całości ( B. Russell 1902) List okazał się bardzo ważnym krokiem nie tylko w poszukiwaniu rozwiązań związanych z paradoksami, ale co najważniejsze pośrednio wskazywał na ich przyczynę. Dzięki nie$\mathrm{mu}$ po raz pierwszy filozofia Zachodu mogła uświadomić sobie problemy związane bezpośrednio z konstrukcją pojęcia zbioru i jego językowej reprezentacji.
} 


\section{Sławomir Sikora: Metody konstrukcji pojęcia zbioru w problemie interpretacji tez Hui Shi}

każde wobec tego pojęcie posiada ekstensję, a pojęcia bez ekstensji, jak zauważył Cantor, prowadzą do sprzeczności.

Podsumowując: Frege wyszedł od pojęcia, by dojść do zbioru rozumianego jako jego zakres. Jest to intensjonalna konstrukcja zbioru. Cantor, odmiennie niż Frege, zamiast wychodzić od pojęć w celu otrzymania zbiorów jako ich zakresów, pyta, które pojęcia (lub predykaty) mają zbiory jako ekstensję. W ten sposób rzecz ujmując, tylko pojęcia posiadające ekstensję mogą mieć wielkość lub liczbę. Zamiast, jak tego chciał Frege, wyprowadzać wszystkie zbiory z pojęć, można od razu badać zbiory (Hao Wang, 1997: 20) .

Zwróćmy w tym miejscu pracy uwagę, że oba podejścia - Fregego i Cantora- łączy bardzo istotny związek: zarówno intensjonalna jak i ekstensjonalna koncepcja zbioru budowana jest na zasadzie dystrybucji wyróżnionej i określonej własności $w$.

Dystrybucyjna konstrukcja zbiorów w obu przytoczonych stanowiskach zakłada, że dla każdej dowolnej własności $\Phi$ istnieje taki zbiór $x$ wszystkich tych i tylko tych obiektów $y$, które mają własność $\Phi$.

$$
\exists_{\mathrm{X}} \forall \mathrm{y}(y \in \mathrm{x} \equiv \Phi(\mathrm{y}))
$$

Obie metody budowane są zatem w oparciu o pewnik nazywany w teorii mnogości pewnikiem abstrakcji.

Wyróżniona przeze mnie konstrukcyjna dystrybutywność zbiorów przez całe wieki rozwoju filozoficzno-logicznej myśli Zachodu rodziła antynomie. Dopiero restrykcje nałożone na nią w systemie teorii mnogości ZermelaFrenkla, oraz teorii typów Russella doprowadziła do likwidacji większości logiczno-semantycznych paradoksów ${ }^{6}$.

Przywołałem w dużym skrócie te dwie myśli, by po pierwsze, wskazać różnice, jakie mogą istnieć $\mathrm{w}$ sposobie definiowania $\mathrm{z}$ pozoru dobrze ugruntowanego $\mathrm{w}$ logice i filozofii zachodniej pojęcia zbioru oraz po drugie, zwrócić uwagę na pewne elementy wspólne tych dwóch ujęć. Elementy wspólne to:

a) zbiory sa przedmiotami;

b) pojęcie zbioru w jednym i drugim przypadku odwołuje się do pewnika abstrakcji, a zbiór tym samym jest zbiorem $\mathrm{w}$ sensie dystrybutywnym;

c) obie koncepcje stoją na stanowisku realistycznym w ontologicznym sporze o uniwersalia, tj. obie opowiadają się za tzw. platonizmem7.

\footnotetext{
${ }^{6}$ Między innymi, zabiegiem zapobiegającym powstawaniu paradoksów nieskończoności na gruncie teorii mnogości ZF było zastąpienia pewnika abstrakcji aksjomatem wyróżniania.

Russell zaproponował teorię typów, w której problem paradoksów rozwiązuje poprzez przyjęcie warunku, że każda klasa zawierać może tylko elementy jednego typu. Klasa klas niebędących własnym podzbiorem tworzy obiekt różny od obiektów wchodzących w jego skład.

Jeszcze inne rozwiązania powstały np. na gruncie teorii mnogości GB von Neumanna - Gödla Bernaysa.

7 Dla każdej niesprzecznej własności $\Phi$ istnieje zbiór dokładnie tych przedmiotów, które tę własność posiadają. Zbiór taki jest odrębnym bytem, ale istnienie jego nie jest tożsame $\mathrm{z}$ istnieniem jego elementów.
} 
Wcześniej zgłosiłem dwie wątpliwości, co do trafności linii interpretacyjnej przedstawionej przez Grahama. Teraz chciałem dołączyć do tych wątpliwości jeszcze jedną. W analizie Grahama zakłada się mianowicie, że pojęcie nieskończoności jest podstawową przyczyną większości paradoksów. Dalej, co pokazał sporządzony wyżej zarys problematyki paradoksów (logicznych i semantycznych) w filozofii zachodniej, okazało się, że problematyka ta jest nierozerwalnie związana z pojęciem zbioru. Wobec tego, uważam, że problem interpretacji tez Hui Shi, w efekcie również do problematyki pojęcia zbioru powinien być sprowadzony.

Chociaż znany był filozofom chińskim semantyczny paradoks kłamcy, to przynajmniej w tezach Hui Shi jego obecności niedostrzegany. ${ }^{8}$

\section{Identyczność a koncepcje zbiorów w tezach Hui Shi}

Powracając na grunt logiki chińskiej, która jest głównym nurtem rozważań, oraz stosując wobec niej metodę badań analogii porównawczej, zadam pytanie:

Czy, jeżeli możliwym byłoby wyodrębnienie z tekstu Hui Shi, zakładanej przezeń koncepcji zbioru, to tym samym pozwoliłoby to na rozwiązanie problemów interpretacji jego tez, ale już nie $\mathrm{w}$ oparciu o pojęcie nieskończoności, lecz o pojęci zbioru właśnie?

Na wstępie postawię hipotezę:

$W$ analizowanym tekście Hui Shi zakłada się dwa sposoby konstruowania pojęcia zbiorów, a dalej bazując na tym dualiźmie, pokazuje się odmienne z perspektywy epistemologicznej porządki świata: dystrybutywny i mereologiczny.

Rozpocznę proces wyjaśnienia hipotezy od odwołania się do wypowiedzi historyka chińskiej myśli filozoficznej Feng Yulana. Źródła paradoksów (przynajmniej niektórych) autor ten doszukiwał się w fakcie nie rozróżniania przez Hui Shi wielu różnych sposobów użycia słowa należeć do klasy, być tym samym (chiń. 同, tong) (Feng Yulan, 2001: 145-147).

Trudno jednak zgodzić się w tym momencie z Feng Yulanem. Wątpliwym jest wielce, aby prawnik, mistrz retoryki, nieodżałowany partner dialektycznych sporów Zhuangzi, mógł reprezentować tak nikły poziom kultury lingwistycznej.

Zauważmy, że znak 同 tong odgrywa pierwszoplanową rolę w tworzeniu kontekstu logicznego tezy (5).

大同而與小同異, 此之謂小同異; 萬物畢同畢異, 此之謂大同異

W tezie tej znak tong występuje na pięciu różnych pozycjach, tworząc pięć związków semantycznych.

\footnotetext{
8 Zob. J. Chmielewski 1981.
} 

interpretacji tez Hui Shi

Semantyczno-logiczna eksplikacja znaku tang w przytoczonym kontekście wymaga - w zgodzie z wymogami metodologii językoznawstwa diachronicznego - odwołania się do źródła bezpośrednio informującego o sposobie użycia tego znaku w okresie, kiedy tekst powstawał.

Wśród setki szkół filozoficznych okresu Han, tylko jedna w sposób systematyczny dociekała problemów lingwistyczno-logicznych. Była to szkoła Późnych Moistów. Współcześni badacze logiki chińskiej zgadzają się z tym, że Kanony Moistów są jedynym wiarygodnym źródłem wiedzy o semantyczno-logicznych interpretacjach pewnych wyrażeń języka starochińskiego. W pracy naszej zakładamy, że dane źródłowe nie stanowią teoretycznych neologizmów jednej ze szkół filozoficznych, lecz są odbiciem ogólnie obowiązującego w owym czasie zwyczaju językowego.

Autorytet Moistów w dziedzinie analizy filozoficzno-logicznej poświadczony został słowami ich filozoficznego opozycjonisty Zhuangzi:

Niemniej mistrz Mo był naprawdę najlepszym człowiekiem na świecie, któremu równego daremnie by teraz szukać. Chociaż jego nauka doprowadzita go do zupetnego wyczerpania, pozostat jej wierny; byt to prawdziwie genialny mędrzec! (Czuang-tsy 1953: 336).

Zawarty w księdze 10 kanon 87 ma brzmienie:

同，重、體、合、類。

Tong (same). Identical, as units, as together, of a kind.

Wyjaśnienie kanonu:

同：二名一實，重同也。不外於兼，體同也。俱處於室，合同

There being two names but one object is the sameness of 'identity'. Not being outside the total is sameness 'as units'. Both occupying the room is the sameness of being 'together'. Being the same in some respect is sameness in being 'of a kind'. (Dsturgeon, Chinese Text Project, 2011, http://ctext.org/ )

Podane przez Moistów wyjaśnienie, pozwala nam na przypisanie znakowi tong czterech funkcji semantycznych:

a) funkcja orzekania o przynależności pewnego elementu $\mathrm{p}$ do pewnego zbioru/gatunku (P) (chin. 類同, lei li tong). W języku starochińskim znak 類 lei znaczy: gatunek, klasa, kategoria (ang. kind, type, class, category, genus).

b) funkcja denotowania tego samego przedmiotu przez dwie różne nazwy (chin. 重同, chong tong). W języku starochińskim znak 重 znaczy: powtórnie, podwójnie (ang. repeat, duplicate).

c) funkcja orzekania, że pewien element p jest częścią pewnej całości (W) (chin. 體同, titi tong). W języku starochińskim znak 體 titi znaczy: części pewnej całości (ang. component parts of an entirety) 
d) funkcja orzekania, że przedmioty: p i m posiadają tą samą lokację (L) (chin. 合同, he ge tong); razem, wspólnie, w tej samej koniunkcji astronomicznej, (ang. together, jointly, conjunction).

Dwie spośród wyodrębnionych funkcji znaku tang znane są w tradycji zachodniej jako zbiorotwórcze.

Przez pryzmat funkcji lei li tong oraz titi tong dokonamy interpretacji tezy (5), analizując kolejno związki;

大同,小同, 小同異, 畢同, 畢異, 大同異.

\section{A.}

Znak tong w znaczeniu: identyczne przez należenie do określonego rodzaju - lei li tong, tworzy związki semantyczne z:

大同 (da tong)- znak 大 $d a$ (pol. duży, wielki) z 同 tong tworzy relację semantyczną: identyczne przez wielkie podobieństwo;

小同 (xiao tong) - znak 小 xiao (pol. maty) z 同 tong tworzy relację semantyczną: identyczne przez małe podobieństwo;

小同異 (xiao tong yi) - znak 異 (pol. różny) z 同 tong i 小 xiao tworzy re-

lację semantyczną: mała różnica podobieństw.

Wyjaśnienie znaczenia znaku 異 yi, odnajdziemy w Księdze 10 Moistów, kanon 91:

二、不體、不合、不類。

Yi (different), not units, not together, not of a kind (Dsturgeon, Chinese Text Project, 2011, http://ctext.org/), co znaczy bycie różnym poprzez nie bycie częścią całości, brak ulokowania w tym samym miejscu, lub nie należenie do tego samego gatunku.

Związek określany jako mała różnica podobieństw 小同異 konstruowany jest na zasadzie wyróżnienia wspólnej własności dla analizowanych przedmiotów. I tak, dla wielkiego podobieństwa 大同 wyróżnia się zbiór przedmiotów (K) takich samych poprzez posiadanie własności konstytutywnej $k$, dla danego gatunku K. Dla małego podobieństwa 小同 wyróżnia się zbiór przedmiotów (A) tożsamych ze względu na posiadanie własności przypadkowej $a$, dla danego gatunku K. K jest wyrażane przez nazwę gatunkową.

Dla przykładu, Platon i Arystoteles są identyczni przez wzgląd na to, że obaj należeli/należą do rodzaju K człowiek (chin. 大同, da tong)i zarazem są identyczni dlatego, że obaj byli/są filozofami (A) (chin. 小同, xiao tong).9 Pierwsza tożsamość jest wielkim podobieństwem, druga zaś jest podobieństwem małym. Różnica między podobieństwami (K) i (A) nazywa się małą różnicą podobieństw (chin. 小同異, xiao tong yi).

\footnotetext{
9 Uprawniona wydaje się być w tym miejscu analogia do arystotelejskiego rozróżnienia na: własności, które wynikają z samej substancji i wskazują na istotę rzeczy oraz przypadłości przypadkowe, które do istoty nie należą i wskazują na przypadkowe własności.
} 
Z teorio-mnogościowego punktu widzenia (K) i (A) są zbiorami wyróżnionymi dystrybutywnie - being the same in some respect is sameness in being 'of a kind'.

Można również zaproponować interpretację zgodnie z którą:

wielkie podobieństwo 大同 (tak jak to było zaproponowane wyżej) znaczy tyle, co 類同( chin. lei li tong) czyli w funkcji orzekania o przynależności pewnego elementu k do pewnego zbioru (K), ale małe podobieństwo 小同, może być odczytane jako 重同 (chin. chong tong) w funkcji denotowania tego samego przedmiotu przez dwie różne nazwy (np. skądinąd znana identyczność znaczenia przy różnych sensach: Gwiazda Poranna i Gwiazda Wieczorna - identyczność przez wspólne znaczenie).

B.

Znak tong w znaczeniu: identyczne przez bycie częścia pewnej całości - ti ti tong, tworzy związek semantyczny 畢同 (bi tong) w którym, bi (pol. zupełnie całkowicie; ang. altogether, completed) wraz z 同 tong tworzą relację semantyczną: bycie identycznym poprzez należenie do pewnej całości, kompletu.

Znak 異 (yi ) w znaczeniu: nie bycie częścia, nie bycie razem, nie należenie do określonego rodzaju, tworzy związek semantyczny 畢異 (bi yi): bycie różnym poprzez nie bycie częścią całości, kompletu.

Zestawienia znaków 畢異 (bi yi) zatem, odczytać należy jako: bycie różnym poprzez nie bycie częścia całości.

O ile różne przedmioty składają się na pewną całość, to ze względu na tą całość są identyczne/podobne - not being outside the total is sameness 'as units'.

Nie wątpliwie, posiłkując się w tym miejscu terminami logiki zachodniej, bi tong oraz titi tong należy interpretować w kategoriach mereologicznych, a nie dystrybutywnych.

Wobec powyższego, jeżeli dowolne przedmioty pozostają $\mathrm{w}$ relacji bycie różnym poprzez nie bycie częścia całości, to wówczas Hui Shi nazywa to dużą różnicą podobieństw 大同異 (da tong yi).

Duża różnica podobieństw jest różnicą zbiorów, ale zbiorów wyróżnionych kolektywnie.

Odnosząc obie interpretacje na powrót do tezy 5 otrzymujemy:

Tong jako należenie do zbioru/rodzaju, użyte w kontekście pierwszej części tezy (5), nazywane jest małą różnicę podobieństw. Odpowiada ono regule konstrukcji zbioru wedle posiadania wspólnej własności.

Z epistemologicznej płaszczyzny rozważań pociąga to za sobą dystrybutywny porządek procesów poznawczych.

Tong jako bycie częścia, użyte w kontekście drugiej części tezy (5), nazywane jest dużą różnicą podobieństw. Odpowiada ono regule konstrukcji zbiorów według kategorii bycia częścią. 
Z epistemologicznej płaszczyzny rozważań pociąga to za sobą mereologiczny porządek procesów poznawczych.

Podsumowując, w tezie (5) Hui Shi, ze względu na dwie funkcje semantyczno-logicznego użycia znaku tong, daje się wyróżnić dwa sposoby konstrukcji zbiorów: zgodnie z postulatem identyczności jako należenia do gatunku oraz zgodnie z postulatem identyczności jako bycie częścią. Rozróżnienie to odpowiada zachodniej tradycji budowy zbiorów dystrybutywnych w pierwszym przypadku, oraz mereologicznych w drugim.

W tezie (5) dwa porządki świata: dystrybutywny i mereologiczny nie wykluczają się, lecz są względem siebie komplementarne.

Niniejszym, sformułowana wyżej hipoteza o dwóch porządkach teorio -poznawczych została uzasadniona poprzez semantyczno - logiczną analizę znaku tong użytego w tezie (5) oraz pośrednio przez słowa samego mistrza Hui Shi:

Przedmiot wywodzi się z podmiotu, a podmiot zależy od przedmiotu. To jest zasada powstawania przeciwieństw. W każdym razie gdzie jest życie, tam jest śmierć; gdzie jest śmierć tam jest życie (Czuang-Tsy 1953: 59).

Człowiek rodząc się zaczyna umierać - teza (4).

W odmienny sposób aniżeli z perspektywy pojęcia nieskończoności, możemy obecnie spojrzeć na pozostałe tezy Hui Shi.

Na początek, jako przykład przedstawię analizę tezy (8) Hui Shi:

Połączone pierścienie da się rozłączyć.

W tym celu sięgam do formatu rozumowania, które zostało zastosowane przez Stanisława Leśniewskiego w jego krytyce koncepcji zbioru Cantora i paradoksów Russell'a w artykule (Leśniewski, 1914).

Tym samym jest to próba zastosowania mereologicznej teorii zbiorów w interpretacji podstawowych pojęć logiki chińskiej.

Przedstawiona przez Leśniewskiego argumentacja w istocie sprowadza się do wykazania:

a) przeciw Cantorowi, że dowolny zbiór $\mathrm{M}$ i jego jedyny element $\mathrm{m}$ są tym samym przedmiotem;

b) przeciw Fregemu, że klasa abstrakcji pojęcia nie wyznacza jednoznacznie jego zakresu;

c) przeciw Russellowi, że jeżeli klasa nie jest swoim elementem, to nie jest klasą.

Z perspektywy historycznej aksjomatyzacja teorii zbiorów kolektywnych nazywana mereologią, była konsekwencją krytycznego stanowiska jej autora w stosunku do wymienionych wyżej trzech zarzutów.

Leśniewski, jak wiadomo w odróżnieniu od Cantora i Russella, w swojej ontologii formalnej i mereologii nie hipostazuje nazw przedmiotów abstrakcyjnych. Według niego przedmioty takie nie istnieją. W ontologii formalnej rozwija on jedynie hierarchię wyrażeń różnych kategorii syntaktycznych. Konsekwentnie twierdzi, że o istnieniu możemy mówić tylko w przypadku przedmiotów konkretnych (Simons, P. 1998:1-24). 


\section{Slawomir Sikora: Metody konstrukcji pojęcia zbioru w problemie interpretacji tez Hui Shi}

Dla prac, w których podejmuje się problem analizy porównawczej logiki chińskiej i zachodniej, ważnym jest fakt, że poglądy Leśniewskiego dotyczące ontologicznego statusu pojęcia zbioru, są znaczenie bliższe nominalistycznie zorientowanej chińskiej filozofii języka aniżeli realistyczne ujęcia Cantora i Russell'a ${ }^{10}$.

Mereologiczna konstrukcja pojęcia zbioru opiera się na jednym terminie pierwotnym być częścia i charakteryzowana jest w oparciu o trzy podstawowe aksjomaty:

1. jeżeli $x$ jest częścią $y$, to $y$ nie jest częścią $x$;

2. jeżeli $x$ jest częścią $y$ oraz $y$ jest częścią $z$, to $x$ jest częścią $z$;

3. jeżeli każde $a$ jest tym samym przedmiotem co $x$ lub częścią $x$, każde $a$ jest tym samym przedmiotem co $y$ lub częścią $y$ i przy wszelkim $\mathrm{z}$ - jeśli $z$ jest częścią $x$ lub $z$ jest częścią $\mathrm{y}$ - to pewien przedmiot będacy tym samym przedmiotem co $z$ lub częścią $z$, jest $a$ lub jest częścią pewnego $a$ - to x jest $y$;

Relacja bycia częścią jest zwrotna, przechodnia i antysymetryczna. Element elementu pewnego zbioru jest elementem tego zbioru. ${ }^{11}$

$\mathrm{Z}$ teoriopoznawczego punktu widzenia, mereologiczne należeć do zbioru będzie rysowało zupełnie inny porządek ,świata” od należeć do zbioru w sensie dystrybutywnym.

$\mathrm{W}$ celu wyjaśnienia problemu nierozłączne/rozłączne w tezie Hui Shi w pierwszym kroku zakładam, że połączone pierścienie są nierozłączne.

Przyjmuję tym samym, że tworzą pewną całość (P).

Całość (P) składa się z dwóch elementów: pierścienia A i B.

Zgodnie $\mathrm{z}$ tym, co udało się ustalić $\mathrm{w}$ paragrafie wyżej, w języku starochińskim wyraża się to przez semantyczną funkcję orzekania, że przedmioty A i B:

a. posiadają tą samą lokację (P) (identyczność 合同, he ge tong);

b. elementy A i B należą do zbioru (P) ze względu na własność $w$ (identyczność 類同, lei li tong);

c. pewne elementy A i B są częścią pewnej całości (P) (identyczność 體同, titi tong).

a)
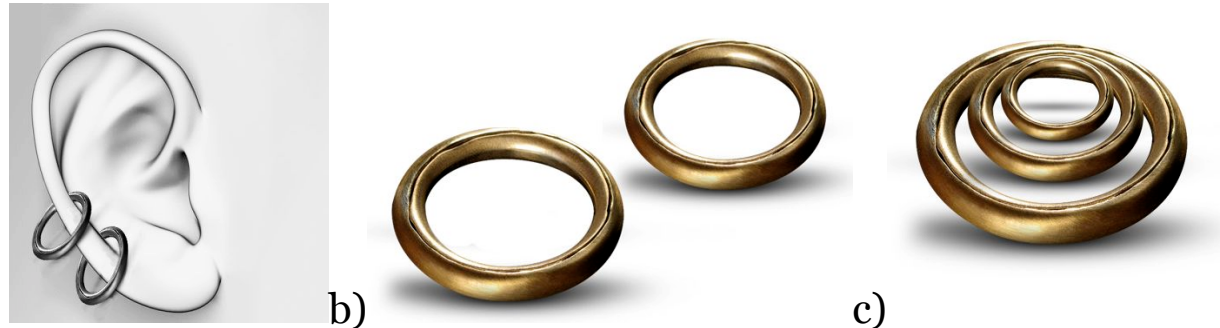

c)

Rys.1. Obrazy odpowiadają kolejno relacją: hege tong, lei li tong, titi tong

\footnotetext{
10 Problem nominalistycznej koncepcji znaczenia w logice chińskiej (ang. nominalised concept of meaning) analizuje Ch. Harbsmeier (Harbsmeier, 1998, s. 189-193).

11 Pełną aksjomatyką teorii zbiorów kolektywnych „,mereologii” podaje Leśniewski w pracy $O$ podstawach matematyki (Leśniewski, 1927).
} 
Ad. a.

Bez większych wątpliwości można przyjąć, że dwa połączone pierścienie A i B pozostają we wspólnej lokacji (P).

Wniosek.a. Pierścienie A i B są nierozłączne ze względu na bycie we wspólnej lokacji. Relacja wyrażana w języku chińskim przez 合同, he ge tong.

Ad. b.

Oba elementy A i B posiadają wspólną własność - bycie pierścieniem, która konstytuuje zbiór (P) ze względu na nią właśnie.

W ogólności, reguła tworząca zbiór (Z) poprzez dystrybucję określonej własności ,,a” daje się wyrazić następująco:

Pewien przedmiot P należy do zbioru $(Z)$ wtedy, gdy:

1. (Z) jest zbiorem przedmiotów ,a"

(zbiór wszystkich przedmiotów, które są ,a”);

2. P jest a.

Przykład: dowolny pierścień $\mathrm{P}$ należy do zbioru pierścieni (Z), ponieważ jeżeli słowo a zostaje użyte w znaczeniu pierścień, to zachowane są warunki:

1. Zbiór pierścieni (Z) jest zbiorem przedmiotów „a”;

2. Pierścień $P$ jest a (pierścieniem).

Kontrprzykład: dowolny kot $\mathrm{K}$ nie należy do zbioru pierścieni (Z), ponieważ jeżeli weźmiemy słowo ,a” w znaczeniu pierścień to zachowany jest warunek:

1. Zbiór pierścieni (Z) jest zbiorem przedmiotów „,a”;

ale nie jest zachowany warunek 2 ,

2. Kot K nie jest a (pierścieniem).

Przyjmując powyższą ogólną zasadę budowy zbiorów, a dalej stosując ją do połączonych pierścieni A $i$ B z tezy (8) Hui Shi, można stwierdzić, że tworzą one zbiór (Z) ) ze względu na własność bycia pierścieniem (chin. 類同, lei li tong ( obraz b, rys.1).

Zbiór (Z) jest jednością (Cantorowskie als Eine).

Wniosek.b. Pierścienie A i B są połączone ze względu na to, że należą do zbioru (Z) wyznaczonego przez własność bycia pierścieniem. Relacja wyrażana w języku chińskim przez 類同 lei li tong.

Ad. C.

Chińska relacja titi tong orzeka, że elementy (x) i (y) są identyczne, o ile są częścią tej samej całości (z).

Aby rzecz przedstawić formalnie musimy założyć istnienie pewnego trzeciego elementu (z) całości, takiego, że zarówno (x) jak i (y) jest częścią $(\mathrm{z})$ :

$\forall \mathrm{x} \forall \mathrm{y} 9 \mathrm{z}(\mathrm{x}$ jest częścią z $\wedge$ y jest częścią z) 


\section{Slawomir Sikora: Metody konstrukcji pojęcia zbioru w problemie interpretacji tez Hui Shi}

Rozpatrywane pierścienie A (element x) i B (element y) można traktować jako nierozłączne wtedy, gdy założy się istnienie pewnego trzeciego elementu (z), którego częścią jest zarówno pierścień A jak i pierścień B (obraz c, rys.3).

W tezie Hui Shi jednak o całości (z) której elementami są pierścienie A i B mowy nie ma.

W drugim kroku wyjaśniania tezy (8) zakładam, że pierścienie, które były wcześniej połączone są rozłączone.

Jeżeli elementy A i B zachowują swoją konstytutywną cechę bycia pierścieniem to rozłaczenie ich jest nie możliwe ze względu na operator abstrakcji. Rozdzielenie ich jest możliwe jedynie w dwóch przypadkach: wtedy, gdy nie posiadają wspólnej lokacji lub nie są częścią tej samej całości.

O ile w odniesieniu do przypadku pierwszego nie trudno podać sposoby możliwego rozdzielenia pierścieni tak, by znalazły sobie różną lokację, to w przypadku drugim koniecznym staje się powrót do semantycznej relacji titi tong i jej mereologicznej interpretacji.

Zakłada ona istnienie elementu (z), którego częściami są pierścienie A i B.

Po rozdzieleniu dwóch części właściwych pewnej całości, zawsze pozostaje pewna reszta.

Zależność tą oddaje mereologiczna reguła mocnej suplementacji (strong supplementation) :

$\neg \mathrm{P} y x \rightarrow \exists z(\mathrm{P} z y \quad \neg \mathrm{Oz} x) ;$

gdzie:

P- relacja bycia częścia

O- relacja $\exists z(\mathrm{P} z x$ Pzy).

Jeżeli pierścień B-(y) nie jest częścią A-(x), to nie istnieje element (z) którego częściami są zarówno A i B. Jeżeli takiego elementu zabraknie, to pierścień A nie będzie w relacji bycia częścia całości (z) oraz pierścień $\mathrm{B}$ nie będzie w relacji bycia częścią całości (z). Sytuację taką obrazuje rysunek 2.

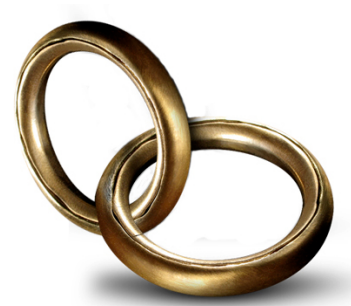

Chociaż z pozoru pierścienie są połączone, to mereologicznie są roz łączone.

Ze względu na mereologiczną relację titi tong, pierścienie zostaną rozdzielone.

Konkludując: połączone pierścienie można rozłączyć. To, co tworzy całość - zbiór - z perspektywy porządku dystrybutywnego, nie musi być całością 
- zbiorem - z perspektywy innego porządku. Obrazuje to relacja wyrażana w języku chińskim przez 體同 titi tong.

W tezie (3), z perspektywy porządku dystrybutywnego góry należą do zbioru (W) rzeczy wysokich ze względu na własność $w$, mokradła zaś należą do zbioru (N) rzeczy niskich ze względu na własność $n$. W mereologicznym porządku jedne i drugie są jednak elementami pewnej całości (relacja 體同 titi tong) i jako jej części są tym samym.

Państwa mają granice. Zgodnie z przekonaniem panującym w starożytnych Chinach, granica może być lądowa albo wodna. Tam, gdzie nie ma wyróżnionych jej własności, tz. nie jest ona lądowa ani wodna(np. mokradła porośnięte trzciną), tam granicy nie ma (teza (6)).

Ale, w porządku mereologicznym Państwo Srodka, jest calościq i wobec tego faktu granice posiadać musi, chociaż nie da się jej wyróżnić poprzez określone własności. Państwo ma i nie ma granicy jednocześnie.

Na koniec tej części pracy pozwolę sobie na uwagę o charakterze komparatystycznym. Zachodnia filozofia za sprawą Arystotelesa i jego kontynuatorów rozpoznała, doskonale zanalizowała i formalnie opisała dystrybutywne oraz kolektywne koncepcje zbioru. Tradycja chińska, jak pokazaliśmy wyżej, oprócz dwóch wymienionych sposobów budowy zbiorów, operowała również trzecim. Relacja wspólnej lokacji nie ma swego odpowiednika w tradycji filozoficznej Zachodu.

\section{Ontologiczna jedność Natury}

Zestawienie chińskich znaków 天地 (chin: tian di) niebo i ziemia jest często używane w znaczeniu natura. Druga część tezy (10):

Niebo i ziemia stanowia jedno ciało może brzmieć:

Cała Natura stanowi jedno ciało (Chmielewski w: Czuang-Tsy 1953: 345).

Zakładając jednoczśnie trafności przeprowadzonej interpretacji tezy (8) i

(5) w kategoriach mereologicznej i dystrybutywnej teorii zbiorów, można zauważyć, że istnieje możliwość wprowadzenia, w oparciu o zaksjomatyzowany system formalny ontologii i mereologii Leśniewskiego, definicji uniwersum.

Pominę w tym miejscu formalną drogę budowy definicji, wskazując w tym temacie na prace Lejewskiego $(54,55)$ i Clay'a $(75)$.

Definicja:

Dla wszelkiego przedmiotu a, a jest częściq , uniwersum” wtw, gdy a jest a, oraz a należy do klasy przedmiotów istniejących.

Wszelkie przedmioty są ze sobą powiązane przez przynależność do klasy przedmiotów istniejących. Pozwala to, na gruncie mereologii, na przyjęcie relacji wyrażającej związek:

underlap (pewne $\mathrm{x}$ jest powiązane wspólnym podkładam z pewnym $y$ ):

Uxy $=_{\mathrm{df}} 9 z(x$ jest częścią $z \wedge y$ jest częścią $z)$ 


\section{Sławomir Sikora: Metody konstrukcji pojęcia zbioru w problemie interpretacji tez Hui Shi}

Relacja Uxy na poziomie metateoretycznym wymaga przyjęcia założeń o istnieniu uniwersalnego bytu ( ang. universal - entity), którego częścią jest każdy dowolny przedmiot (Casati R. and Varzi A. C. 1999, 29-99) .

W konsekwencji można powiedzieć również, że istnieje pewien uniwersalny byt, którego wszystko jest częścią. Natura tworzy pojedynczą całość i jako części tej całości powinniśmy się troszczyć o wszystkie jej elementy.

Jak nie trudno zauważyć, Hui Shi w tezie (10) formułuje ontologiczny postulat istnienia bytu w sensie kolektywnym - uniwersum, zbiór wszystkich przedmiotów.

Tym samym upoważnia nas to do stwierdzenia, że teza (10) może być zinterpretowana, jako formalna konsekwencja dualnego porządku epistemologicznego wyrażonego w (5) ${ }^{12}$.

\section{Podsumowanie}

W przekazanych przez Zhuangzi tezach mistrza Hui Shi, można odnaleźć lapidarny zarys modelu systemu filozoficznego. Zakładająca dualizm konstrukcyjny procesów poznawczych podmiotu poznającego epistemologiczna teza (5), jest głównym teoretycznym postulatem takiego systemu.

Ontologia (teza 10), podobnie jak ma to miejsce $\mathrm{w}$ zachodniej filozofii transcendentalnej Kanta, jest konsekwencją przyjętych założeń teoriopoznawczych w tezie (5). Poprzez uniwersalny byt, wszystkie elementy rzeczywistości tworzą jedną całość, która odsłania nam się tylko w porządku mereologicznym.

Porządek dystrybutywny odsłania natomiast wielość przedmiotów, co przynajmniej w przypadku daoizmu chińskiego nie było pożądanym celem aktywności intelektu ludzkiego.

Niebo i ziemia sa moimi rówieśnikami, świat przedmiotów stanowi jedność, czyż może nie być nazwy na jedność. Jedność i jej nazwa stanowia dwójcę, a dwójca stanowi trójcę. Od tego poczq̨wszy posuwając się dalej

12 Dwie tezy Hui Shi (9) i (2) nie wydają sie być bezpośrednią konsekwencją poglądów filozoficznych ich autora, lecz mogą być wykorzystaniem dla retorycznych celów osiągnięć starożytnej nauki chińskiej.

Ziemia ma kształt kuli, co dobrze opisywała starożytna astronomia i geologia Chińska. (Needam, J. 1984).

Kula jest opasana siatką hipotetycznych okręgów (współcześnie nazywane są południkami i równoleżnikami). W każdej takiej krzywej początek i koniec można wyznaczyć w dowolnym jej punkcie. Do tego punktu docieram zawsze wyruszając zarówno na południe jak i na północ. Bez względu na to czy wyruszę na południe czy na północ, zawsze dotrę w to samo miejsce.

To, co ma długość, szerokość i wysokość (teza 2) oraz wagę, można gromadzić i objąć zmysłami. Istnieją też rzeczy i zjawiska, których gromadzić nie sposób, ale mające wielkość i dające się ująć intelektem. Obok płaszczyzny składającej się z pojedynczych punktów, są to także na przykład kosmologiczne siły Yin Yang oraz pole magnetyczne oddziaływujące na igłę kompasu. Dualizm korpuskularno-falowy był obecny w nauce chińskiej na dwa tysiące lat przed jego sformułowaniem we współczesnej nauce.

Próbę opisania rozwoju nauki chińskiej w zestawieniu z tradycją europejską przedstawił J. Needham w: Wielkie Miareczkowanie. Nauka i społeczeństwo w Chinach i na zachodzie (Needam J., 1984). 
nawet biegty rachmistrz nie osiągnie końca, a cóż dopiero zwykli ludzie (Czuang- Tsy 1953: 62).

Przestrzeń dyskursu filozoficznego jest z góry limitowana przez wielka jedność 大無 oraz z dołu - przez mała jedność 小無 (teza 1).

Pierwsza część tezy (10) natomiast:

Jednakowa miłościa otaczajmy wszystkie istoty;

może być zinterpretowana, jako postulat filozofii praktycznej i tym samym pełnić analogiczną funkcję jaką pełni zasada imperatywu kategorycznego I. Kanta w nowożytnej filozofii zachodniej.

Powszechnie interpretowane jako paradoksalne tezy 3, 4, 7, $8 \mathrm{w}$ świetle zaprezentowanej wyżej argumentacji są obecnie traktowane jako egzemplifikacja przyjętego modelu filozoficznego.

Zauważmy, że o ile paradoks rozumiany jest jako argumentacja prowadząca do wniosków, które nie sposób przyjąć ze względu na jego przesłanki, to tezy Hui Shi paradoksami nie są.

Autor przyjął w tezie (5) wyraźne rozróżnienie dwóch porządków epistemologicznych: dystrybutywnego i kolektywnego, a w ślad za tym starał się pokazać, że zgodnie z (10) świat w sobie nie rysuje żadnych rozróżnień. Rozróżnienia są zakładane przez konwencje językowe w ramach porządku dystrybutywnego, które to konwencje zakładają kryteria odróżniania tego samego i różnego. Oprócz tych norm nie ma żadnych pozaludzkich uprzywilejowanych naturalnych rodzajów albo rozróżnień.

Przeprowadzona analiza formalna 10 tez wydaje się potwierdzać opinię dotyczącą Hui Shi i epistemologii daoizmu chińskiego, wyrażoną przez Ch. Hansena:

Rejecting all distinctions is tantamount to rejecting language and vice-versa. Hui Shi, from the fragments available, tended to conclude from the relativity of distinctions to perspective that there were no distinctions in reality. Someone familiar with linguistic work would have good grounds for rejecting this inference. Zhuangzi's point here is that rejecting distinctions is implicit in the claim that "all is one." We cannot make it without making a distinction. "Having said, "all is one" have we managed to say anything?" Zhuangzi saw that we cannot soundly draw an absolute conclusion about reality from relativist premises about words, distinctions and reference (Hansen 2011).

$\mathrm{Z}$ perspektywy badań porównawczych warto podkreślić, że filozofia chińska w odróżnieniu od jej zachodniej rówieśniczki, swój dyskurs epistemologiczny budowała na komplementarnie rozumianym dualizmie: $k o-$ lektywny porzadek/ dystrybutywny porządek. Ta druga natomiast, w tym samym czasie swoją refleksję teoriopoznawczą skupiła na opozycji aprioryzm/ empiryzm, wyznaczając sobie kierunek sporu teoriopoznawczego na tysiąclecia. 


\section{Sławomir Sikora: Metody konstrukcji pojęcia zbioru w problemie interpretacji tez Hui Shi}

\section{Bibliografia}

Anellis, I.H. 1991. Perspectives on the History of Mathematical Logic. w: Drucker T., "The first Russell paradox," Cambridge, Mass.: Birkäuser Boston. pp. 3346.

Cantor, G. 1883. Pojęcie zbioru, w: Murawski, R. 1986.

Cantor, G. 1887. O pozaskończoności, w: Murawski, R. 1986.

Casati R. and Varzi A. C. 1999. Parts and Places: The Structures of Spatial Rep-

resentation, Cambridge (MA), MIT Press

Chmielewski, J. 1981. Zasada redukcji do absurdu na tle porównawczym, w:

Studia Semiotyczne XI, s. 121-106.

Chmielewski, J. 2009. Language and logic in ancient China: collected papers on the Chinese language and logic, ed. by Marek Mejor; Polska Akademia Nauk. Komitet Nauk Orientalistycznych.

Clay, R.E. 1975. Single axioms for atomistic and atomless mereology, Notre Dame Journal of Formal Logic, XVI.

Czuang - Tsy. 1953. Nan Hua Czen King. Prawdziwa Księga Potudniowego Kwiatu, tłum. W. Jabłoński, J. Chmielewski, O. Wojtasiewicz, T. Żbikowski, Warszawa: PWN.

Dstrugeon, Chinese Text Project, 2011, http://ctext.org/.

Diogens Laertios, 1984. Żywoty i poglądy stynnych filozofów, Warszawa: PWN.

Feng, Youlan. 2001. Krótka historia filozofii chińskiej, Warszawa: PWN.

Frege, G. 1977. Pisma semantyczne, Warszawa: PWN.

Graham, A. 1978. Later Mohist Logic, Ethics and Science. Hong Kong and London: Chinese University Press.

Graham, A. C. 1989. Disputers of the Tao: Philosophical Argument in Ancient China. La Salle, Illinois: Open Court.

Hansen, Ch. 1983. A Tao of Tao in Chuang Tzu. w: Mair, Victor, ed. „Experimental Essays on Chuang-tzu”, Honolulu: University of Hawaii Press. 2455.

Hansen, Ch. 1983. Language and Logic in Ancient China. Ann Arbor: University of Michigan Press.

Hansen, Ch. 2011. Relativistic Skepticism in the „Zhuangzi” http://www.hku.hk/philodep/ch/Skeptic.htm, 11.02.2011.

Hao, Wang. 1997. Czym jest logika? w: Woleński, J. (red.) Filozofia logiki, Warszawa: Wydawnictwo Spacja-Fundacja Altheia.

Harbsmeier, Ch. 1998. Language and Logic. w: Needham, J. „Science and Civilisation in China”. Cembridge University Press.

Knobloch, J. 1994. Xunzi. A Translation and Study of the Complete Works, Stanford: Stanford University Press.

Knobloch, J., Riegel, J. 2000. The annals of Lü Buwe, Stanford: Stanford University Press.

Laozi. 2006. Laozi. Księga dao i de z komentarzami Wang Bi, tłum. Wójcik, A.I. Kraków: Wydawnictwo Uniwersytetu Jagiellońskieego.

Lejewski, C. 1954. A constribution to Leśniewski’s mereology, w: „Rocznik Polskiego Tow. Naukowgo na Obczyźnie" V.

Lejewski, C. 1955. A new axiom for merology, w: „Rocznik Polskiego Tow. Naukowgo na Obczyźnie” VI. 
Leśniewski, St. 1914. Czy klasa klas nie podporzadkowanych sobie jest podporządkowana sobie? w: Przeglad Filozoficzny, XVII/I.

Leśniewski, St. 1927. O podstawach matematyki, w: Przegląd Filozoficzny, $\mathrm{XXX} / 2-3$.

Leśniewski, St. 1928. O podstawach matematyki, w: Przegląd Filozoficzny, $\mathrm{XXXI} / 3$.

Lucas, T, 1993, Hui Shih and Kung Sun Lung: an Approach from Contemporary Logic, Journal of Chinese Philosophy, 20(2): 211-55.

Murawsk,i R. 1986. Filozofia matematyki. Antologia tekstów klasycznych, Poznań: Wydawnictwo Naukowe UAM.

Murawski, R. 2001. Filozofia matematyki. Zarys dziejów, Warszawa: Wydawnictwo Naukowe PWN.

Russell, B. 1902. List do Fregego, w: Murawski, R. 1986 s.221.

Simons, P. 1998. Nominalizm in Poland, w: Srzednicki, J.T., Stachniak, Z. „Leśniewski's systems protothetic”, Kluwer Academic Publishers.

Simons, P. M. 1987. Parts. A Study in Ontology, Oxford: Clarendon. 